\title{
THE CAPE AND NATAL SPECIAL PARTNERSHIPS LIMITED LIABILITY ACTS. A STATUTORY HISTORY
}

\section{JJ Henning*}

\section{Introduction}

Limited partnerships were provided for in the Cape and Natal colonies by the Cape Special Partnerships Limited Liability Act of $1861^{1}$ (hereinafter "the Cape Act") and the Natal Special Partnerships Limited Liability Act of $1864^{2}$ (hereinafter "the Natal Act") respectively. A limited partnership may be described as the statutory equivalent of the common-law partnership en commandite.

The partnership en commandite, which developed in the European ius commune, confers limited liability on the non-managing partners. The partner en commandite is not answerable to the creditors of the firm, but solely to his fellow partners, to whom he is only accountable for his share of partnership losses up to the amount of his agreed capital contribution. In this way, a partner en commandite is shielded from the partnership creditors, and the limit of his partnership liability is predetermined. ${ }^{3}$

1 Act 24 of 1861, amended by the Cape Special Partnerships Limited Liability Amendment Act 12 of 1906 .

2 Enacted by Law 1 of 1865 , of which s 14 provided: "The Law shall be cited for all purposes as 'The Special Partnerships Limited Liability Act, 1864'."

3 HR Hahlo \& E Kahn The Union of South Africa: The Development of its Laws and Constitution (Cape Town, 1960) at 699.

* Senior Professor of Mercantile Law, Faculty of Law, University of the Free State; Professor Extraordinarius of Mercantile Law, College of Law, University of South Africa.

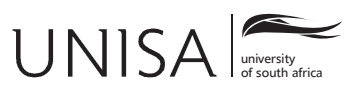


A limited partnership consists of one or more general partners, who are liable for all the debts and obligations of the firm and entitled to manage the firm's affairs, as well as one or more limited partners, whose liability for the debts and obligations of the firm is limited in amount and who are excluded from management functions. The limited partnership is thus designed to allow passive investors in an enterprise to share profits without becoming responsible for losses and liabilities beyond the amount they invest in the business. The function of the limited partnership differs from that of the recently developed limited liability partnership, which enables partners who are actively involved in the business of their partnership also to limit their liability for the partnership obligations. ${ }^{4}$

Recently, there has been a renewed interest in and several initiatives aimed at the modernisation of limited partnership legislation in several jurisdictions, including the United Kingdom, New Zealand, the United States and Ireland. ${ }^{5}$ In various jurisdictions, the tax-transparent structure of the limited partnership makes it an attractive vehicle for institutional investors such as pension funds or insurance companies, which are partially or wholly tax-exempt. It enables them to invest jointly with tax-paying entities, such as property companies, without losing their tax benefits. The same features have made limited partnerships suitable for use in urban regeneration projects, bringing together public authorities, institutional investors and property developers. In Germany, the hybrid limited partnership, the Gmbh \& Co KG, with a private company as general partner and the limited partners as shareholders in the private company, has for various reasons attained significant popularity as a vehicle for small and medium business enterprises. The recent rise of limited and commanditarian partnerships with corporate partners only, have increased the importance of these partnerships as vehicles for unincorporated joint ventures. ${ }^{6}$

4 See, in general, RW Hillman, AW Vestal \& DJ Weidner General and Limited Liability Partnerships under the Revised Uniform Partnership Act (St Paul Minnesota, 1996) at 299; E Snyman \& JJ Henning "Developments in the Anglo-American law of partnership: The limited liability partnership as a new form of business enterprise" (2002) TSAR at 129.

5 See, eg, United Kingdom Legislative Reform (Limited Partnerships) Order 2009; New Zealand Limited Partnerships Act 1 of 2008; United States Uniform Limited Partnership Act of 2001 available through Westlaw at http://international.westlaw.com/toc/default.wl? $r s=$ WLIN15.0 $7 \& s c d b=U L A \& v r=2.0 \& a b b r=U L A \& s c r l t=C L I D \_D B 56138932638 \& r p=\% 2 f t o c \% 2$ fdefault . $w l \& s p=i n t u f s-000 \& f n=$ top $\& t f=2004 \& m t=314 \& t c=29 \& s v=F u l l$; Ireland Investment Limited Partnerships Act 24 of 1994.

6 See, in general, C Jaehne \& JJ Henning "Recent developments in German and European Union company law affecting the Gesellschaft mit beschränkter Haftung" 2007 International and Comparative Corporate Law J at 21; W Giesen Die GmbH \& Co als Rechtsform der Kooperation im Sinne der Ausgliederung und Übertragung von Funktionen wirtschaftlich und rechtlich selbständiger Unternehmen auf ein gemeinsames Unternehmen (Münster, 1986) at 14; JJ Henning Perspectives on the Law of Partnership in South Africa (Cape Town, 2014) at 203. 
The Cape and Natal Acts were introduced in the two colonies notwithstanding the reception of the partnership en commandite and its recognition as a feature of South African law as early as the first half of the nineteenth century. ${ }^{7}$

Although the limited partnership did not prove very popular, and the Cape and Natal enactments were eventually repealed in South Africa, the importance of these colonial statutes in the context of the South African law of partnership should not be underestimated or ignored. It should be kept in mind that these colonial statutes represent the only stand-alone, contiguous partnership legislation ever introduced in a South African context. Also, the Cape legislation found wider application in another four jurisdictions in Southern Africa.

Although the United Kingdom was identified as the statutory origin of this legislation, its Limited Partnerships Act $1907^{8}$ was introduced more than forty years after the Cape and Natal statutes. In view of some uncertainty surrounding their true origin, this contribution provides an overview of the statutory history of the two colonial limited partnership statutes. The focus is on the relevant statutory provisions in various jurisdictions forming part of this history. ${ }^{9}$

\section{Origins and historical background}

\section{France}

\section{Introduction}

Limited partnership legislation in common-law jurisdictions was initially inspired by the French société en commandite. ${ }^{10}$ The roots of the partnership en commandite can be traced back with certainty to at least the Italian commenda contract of the Middle Ages, although it probably dates back to much earlier constructs. ${ }^{11}$ In essence, the commenda was an arrangement by which an investor entrusted capital to a trader for use in mercantile enterprises, provided that the investor, while not in name a party to the enterprise and though entitled to a share of the profits, would not be liable for

7 Watermeyer $v$ Kerdel's Trustees 18343 Menz 424.

8 Limited Partnerships Act 1907 (7 Edw 7, c 24).

9 I sincerely thank the reference staff of the libraries of the University of the Free State (especially Mrs Hesma van Tonder), the University of Pretoria and PriceWaterhouseCoopers, as well as $\mathrm{Mr}$ Michael Ashe QC SC (Recorder of the Crown Court, England and Wales, and Master of the Bench of the Middle Temple), for making available copies of legislation that are not freely accessible on the internet.

10 R I'Anson Banks Lindley and Banks on Partnership (London, 2010) at 985-986.

11 See W Endemann Studien in den romanisch-kanonistischen Wirtschafts- und Rechtslehre (Berlin, 1874) at 361-364; AD Kessler A Revolution in Commerce (New Haven \& London, 2007) at 141; FJFM Duynstee Commanditaire vraagstukken (Zwolle, 1940) at 9; FJ Troubat The Law of Commendatory and Limited Partnership in the United States (Philadelphia, 1853) at 34; TM Bergstedt "Partnership in commendam - Louisiana's limited partnership" (1960) Tulane LR at 816. 
losses beyond the amount of his investment. ${ }^{12}$ This concept of limiting the liability of non-managing investors spread to French commercial law, emerging as the société en commandite, the precursor of both the present-day commanditarian partnership on the European continent ${ }^{13}$ and the limited partnership in Anglo-American law. ${ }^{14}$ From France, the société en commandite was incorporated into Roman-Dutch law and received in South African law under its French name. Although Van der Linden referred to it as the sociëteit en commendite, Van der Keessel correctly described it as the société en commandite. ${ }^{15}$

\section{Ordinance Pour le Commerce of March 1673}

In 1669, the merchants of Paris, feeling the need for an improved body of commercial law, applied to Louis XIV for constructive action. Eventually, this resulted in the promulgation of the Royal Ordinance of March 1673 entitled Pour le Commerce. ${ }^{16}$ Title IV of the Ordinance devoted fourteen articles to the regulation of commercial partnerships, including partnerships en commandite. Article I provided that all partnerships, whether general or en commandite, had to be created by a written instrument either before notaries or under "private signature". Articles II to VI detailed the requirements concerning the public registration and advertisement of instruments of partnership between merchants and tradesmen. ${ }^{17}$ Pothier maintains

12 Ibid.

13 For example, Kommanditgesellschaft (Germany), Commanditaire vennootschap (the Netherlands).

14 Endemann (n 11) at 361-364.

15 Van der Linden Regtsgeleerd, Practicaal, En Koopmans Handboek (Amsterdam, 1806) at 4112 discusses it as "De Sociëteit, genaamd en commendite", while Van der Keessel Praelectiones Iuris Hodierni ad Hugonis Grotii Introductionem ad Iurisprudentiam Hollandicam (Amsterdam/Cape Town, 1967) at 3217 described it as "de societatibus ad exemplum earum, que in Gallia vocantur sociétés en commandite, contractis". See, also, Van Leeuwen Het Rooms-Hollandsch Recht Op nieuws overgezien en met Aantekeningen uitgebreid door CW Decker (Amsterdam, 1780) 4231 n (b); JM Barels Advysen over den Koophandel en Zeevaert (Amsterdam, 1781) 29 and 260.

16 Also referred to as the Code Savary or Colbert's Code Marchand. See WY Bewes The Romance of the Law Merchant: An Introduction to the Study of International and Commercial Law, with Some Account of the Commerce and Fairs of the Middle Ages vol 1 (London, 1923) at 78-79; SE Howard "Business partnerships in France before 1807" (1932) The Accounting Review at 242. See, also, CJ Forrester "The codification of commercial laws with special reference to the French Ordinance of 1673 and to accounting" (1999) An Invitation to Accounting History available at http://www.cs.trinity.edu/rjensen/readings/history/forrester/a03codes.htm (accessed 1 Dec 2014), who points out that the decisions of the Italian Rote de Genes (Rota Genua) provided some basis for codification. These decisions were lauded and widely accepted up until the mid-eighteenth century, only to be forgotten in comparison with French commercial legislation.

17 In these cases, a summary had to be registered at the office of a local official and published on a bulletin board in a public place, failing which the acts and contracts performed under such partnership would be nullified. Such notice had to contain the names, surnames, ranks and residences of the members of the partnership, and the duration contemplated for its operations. Extension of the duration of the partnership and changes in membership had to be registered and published. For a detailed discussion of these requirements, see RJ Pothier $A$ Treatise on the Contract of Partnership (London, 1854) at 42 82-83. 
that these formalities of registration and publication fell into disuse and were no longer observed. ${ }^{18}$

Articles VII and VIII distinguished between general members (associés) and members en commandite. All general members were jointly and severally liable for the debts of the partnership. Members en commandite were not liable, except up to the amount of their investment. ${ }^{19}$ Article VIII stipulated that this limited liability was subject to the condition that the name of the partner en commandite may not form part of the firm or partnership name. From this condition, the inference was made ${ }^{20}$ that the partner en commandite may neither contract on behalf of the partnership nor take part in the management of the partnership. ${ }^{21}$ Although the ordinance was silent as to what effect the en commandite partner's participation in management would have on his limited liability, a considered body of opinion later existed that such participation would lead to the imposition of full personal liability. ${ }^{22}$ The remaining articles of Title IV ${ }^{23}$ provided for a system of compulsory arbitration of disputes between or among partners ${ }^{24}$ and, notably, that the foregoing provisions were binding upon the widows, heirs and creditors (legal claimants) of the partners. ${ }^{25}$

18 Ibid.

19 According to Pothier (n 17) at 42 82, 22 60-63, 4282 and 62 102, a partnership en commandite was entered into by a trader with a private person (a person not in trade) for a trade that was to be carried on in the name of the trader only, and to which the contracting party (private person) contributed only a certain sum of money, which he brought into the capital of the partnership under an agreement that he was to have a certain share of the profits, if there were any, and in the contrary event, to bear the same share of losses, in which he would nevertheless only be bound to the extent of the capital he had brought into the partnership.

20 Duynstee (n 11) at 41.

21 Idem at 40-41.

22 AD Kessler "Limited liability in context: Lessons from the French origins of the American limited partnership" (2003) J of Legal Studies at 511.

23 Articles IX-XIV.

24 The Ordinance required that a clause binding members to submit such disputes to arbitrators had to be inserted in every deed or instrument of partnership. In the absence of such a clause, one member could nominate an arbitrator, and in the event of the failure of the other member(s) to take similar action, the court would act in his or their stead. Thus, if appointed arbitrators died or were absent for long, substitutes had to be appointed, and the court would have acted to this end if the members did not themselves initiate action. Arbitrators who were unable to agree could appoint an umpire without the disputants' consent, failing which the court could make such an appointment. The ordinance instructed arbitrators to arrive at decisions on the basis of documents and memoranda submitted by the disputants, without court formality and without the necessity of the interested parties being physically present. Arbitration decisions that were arrived at in this way and involved members of a partnership in trade, commerce and banking had to be confirmed in a court.

25 Articles VII and XIX. See Pothier (n 17) at 43 61; Howard (n 16) at 243-244. Note that, at that time, the heirs of a partner were collectively liable for all of the partner's debts, although each was liable only to the extent of the share that he was entitled to as heir of the deceased. See Pothier (n 17) at 696. 
The Ordinance of 1673 may be thought of as having provided, in Title IV, the first codified partnership law for the French business community.

\section{Code de Commerce of 1807}

Title IV of Louis XIV's Ordinance Pour le Commerce of 1673 formed the basis of the Book 1 Chapter III of the French Code de Commerce of 1807, which dealt with commercial partnerships. ${ }^{26}$

The Code de Commerce also provided for detailed registration and publication requirements of commercial partnerships, including partnerships en commandite, along the lines of the Ordinance. ${ }^{27}$ Partnerships were commercial when their object was to carry on the acts of commerce detailed in articles 632 and 633 of the Code de Commerce. $^{28}$

According to article 23 of the Code de Commerce, a partnership en commandite was contracted between one or more partners who were jointly and severally liable for partnership obligations (commandites), and one or more partners who were mere holders of capital, called commanditaires or partners en commandite. It was carried on under a firm or partnership name, which necessarily had to be that of one or more of the partners who were jointly and severally liable. Although it appears that at one time, the partnership en commandite was carried on in the name of a single manager only, it was later carried on in the name of a firm composed of two or more managing partners, and the capital was often divided into shares. ${ }^{29}$

In a partnership en commandite with several partners jointly and severally liable by name at the same time, whether all managed together or one or more managed on behalf of all, the partnership was simultaneously an ordinary commercial partnership trading under a joint or firm name (en nom collectif) with respect to these partners, and a partnership en commandite with respect to those who merely provided the capital. $^{30}$

26 See L Goirand The French Code of Commerce (London, 1860) at 4.

27 Articles 41-46. See OD Tudor A Treatise on the Contract of Partnership by Pothier (London, $1854)$ at 58. Articles $42-46$ were repealed in 1867. In addition to setting detailed registration requirements, arts 43 and 44 required the extract of the contract to contain the Christian names of all partners, except the partners en commandite, and had to be signed by all partners, except the partners en commandite.

28 These included all operations of public banks; operations relating to exchange banking and commission; the purchase of produce and merchandise for resale or for letting and hiring; any enterprise of manufacture, commission or carriage by land or water; any undertaking to supply goods; agencies; commission agencies; establishments for sales or auction and public amusements; all obligations between traders, merchants and bankers, and transactions in relation to bills of exchange as well as the remittance of money from one place to another.

29 Tudor (n 27) at 42.

30 Code de Commerce art 24. 
The partner en commandite was only liable for partnership losses to the amount of the funds that he had contributed, or ought to have contributed, to the partnership. ${ }^{31}$ The name of the partner en commandite was not allowed to form part of the style of the firm or partnership name. ${ }^{32}$ The partner en commandite was not entitled to perform any act of management nor to be employed in the business of the partnership, not even by virtue of a power of attorney. ${ }^{33}$ In the case of a contravention of this prohibition, the partners en commandite were liable, jointly and severally with the general partners of the firm, for all the debts and liabilities of the partnership. ${ }^{34}$ This provision was later modified to provide that the liability of the partner en commandite was limited to the debts and obligations arising from the acts of management performed by him, and that, according to the number and importance of the acts, he could be declared jointly and severally liable for all the obligations of the partnership, or for one or some only. In addition, it was stipulated that partners en commandite were not rendered liable by acts of mere counsel, advice or guidance. It appears, therefore, that they were able to tender advice, check the operations and generally supervise the transactions of the partnership, without contravening the prohibition. ${ }^{35}$

It was also possible for the capital of a partnership en commandite to be divided into shares, without any derogation of the rules established for this kind of partnership. ${ }^{36}$ Later, a definite distinction was drawn between the ordinary partnership en commandite, referred to as the société en commandite simple, and the partnership en commandite with freely transferable shares, known as the société en commandite par actions. ${ }^{37}$

It should be noted that the French Code Civil provided that if it had been stipulated that, in the event of one of the partners' death, the partnership had to continue with his heir, such arrangement needed to be followed, ${ }^{38}$ although it seems that this was only feasible in partnerships not established intuitae personae. ${ }^{39}$

31 Code de Commerce art 26.

32 Code de Commerce art 25.

33 Code de Commerce art 27.

34 Code de Commerce art 28.

35 Goirand (n 25) at 565.

36 Code de Commerce art 38.

37 Goirand (n 26) at 566. See A Santuari "The société en commandite par actions in France during the first half of the nineteenth century: Historical developments and comparative outlines" (1997)

3 Fundamina at 104.

38 Code Civil art 1868: "If it has been stipulated that, in case of the death of one of the partners, the partnership shall continue with his heir, or only between the surviving partners, such arrangements shall be followed: in the second case, the heir of the deceased has a right only to a distribution of the partnership, regard being had to the situation of such partnership at the time of the death, and he has no participation in any ulterior claims, except in so far as they are a necessary consequence of what was done before the death of the partner whom he succeeds." Translation available at $h t t p: / /$ www.napoleon-series.org/research/government/code/book3/c_title09.html\#chapter4 (accessed 6 Nov 2014). See, also, Tudor (n 27) at 106.

39 Goirand (n 26) at 93. 


\section{Irish "Anonymous Partnerships Act" of 1781}

English common law does not permit a partner to limit his liability for firm debts to his contribution to its capital, and limited partnerships analogous to partnerships en commandite had to be introduced by statute..$^{40}$ Limited partnerships, therefore, are creatures of statute in common-law jurisdictions.

The first limited partnership legislation enacted in a common-law jurisdiction appears to be the Irish "Act to promote Trade and Manufacture, by regulating and encouraging Partnerships" of $1781,{ }^{41}$ often referred to as the Anonymous Partnerships Act. This Irish statute, which took effect on 24 June $1782,{ }^{42}$ provided for acting partners and anonymous partners under a written partnership contract signed by the parties and witnessed ${ }^{43}$ and registered at the public registry office. ${ }^{44}$

The acting partners were to manage and conduct the business of the partnership under their collective names, with the addition of "and company". Every acting partner was fully liable for all partnership obligations. ${ }^{45}$ The statute granted limited liability to anonymous partners, provided that they took no part in the management of the partnership and their names were not mentioned in the firm of the partnership. Such partners" liability was limited to the "full sums subscribed and paid" by them. ${ }^{46}$ They had to pay a quarter of their subscribed contributions to the acting partners upon the execution of the partnership contract, and the balance no later than at the end of the first year. If not, anonymous partners forfeited their contributions and became liable to the partnership creditors for the unpaid balance. ${ }^{47}$

The partnership could be formed for the purpose of buying and selling by the gross, or wholesale, or for establishing or carrying on any manufacture or business, ${ }^{48}$ although the business of "bankers or discounters of money for shopkeepers selling by retail" was expressly excluded. ${ }^{49}$ There was no limitation on the number of partners.

40 Walburn v Ingilby 1 My \& K 61; 39 ER 604; Tudor (n 27) at 76; I'Anson Banks (n 10) at 985-986; FM Burdick The Law of Partnership including Limited Partnerships (Boston, Mass, 1917) at 383.

$4121 \& 22$ Geo III, c 46.

42 In 1782, Ireland obtained legislative independence from Great Britain for the first time since 1495. In 1800, the British and Irish parliaments both passed Acts of Union, which merged the Kingdom of Ireland and the Kingdom of Great Britain with effect from 1 January 1801 to create a United Kingdom of Great Britain and Ireland. See, in general, P Higgins \& JS Donnelly A Nation of Politicians: Gender, Patriotism, and Political Culture in Late Eighteenth-century Ireland (Madison, 2010).

43 Section 1.

44 Section 13. The partnership contract had to contain, inter alia, the names of all the parties, specifying who the acting partners and the anonymous partners were, and the sums respectively subscribed for by each.

45 Section 2 of the "Act to promote Trade and Manufacture, by regulating and encouraging Partnerships" 1781 (21 \& 22 Geo III, c 46).

46 Idem $\mathrm{s} 7$.

47 Idem $\mathrm{s} 4$.

48 Idem $\mathrm{s} 1$

49 Idem $\mathrm{s} 18$. 
Annual financial statements had to be drawn up and signed by all the acting partners and at least two thirds of the anonymous partners. ${ }^{50}$

It has been argued that the Irish statute interfered too much with what should have been left to the discretion of the parties. ${ }^{51}$ For example, contributions to the partnership could not be less than $£ 1000$ per partner and not more than $£ 50000,{ }^{52}$ certain business activities were expressly excluded, the term of the partnership was limited to fourteen years, ${ }^{53}$ and the parties could not withdraw more than $50 \%$ of the profit annually. ${ }^{54}$

An interesting and progressive feature of this legislation was contained in section 8 , which provided that the partnership was not dissolved by death or bankruptcy of all or any of the anonymous partners, unless agreed otherwise. The share of the deceased partners could be inherited, transferred, assigned and even sold at a public auction, and the new owner of the share then had to "stand in the place of the deceased ... partner during the term of the ... partnership" ${ }^{55}$ Similarly, the legislation stipulated that if there were two or more acting partners, the death or bankruptcy of any of them, while one "survived in full credit", will not dissolve partnership, unless agreed otherwise ${ }^{56}$ Provisions such as these disappeared from limited partnership legislation during the nineteenth century and reappeared only in the twentieth century as a modification of the general law of partnership. ${ }^{57}$

The provisions of the Irish statute were so foreign to England that the legislation was included as an appendix to Ker's Report on the Law of Partnership ${ }^{58}$ in $1837,,^{59}$ stating that the effect of the legislation could not be considered beneficial. It appears that after fifty years' experience, few persons had acquainted themselves with, and made use of, the provisions of the statute. It has been suggested that the risk associated with accidental non-compliance with the strict and minute provisions of this act may have been one of the main causes that deterred capitalists from utilising it. ${ }^{60}$ It was repealed in $1862 .{ }^{61}$

$50 \quad$ Idem $\mathrm{s} 5$.

51 See Anon "Limited liability in partnerships" (1855) Law $R$ \& Quarterly J of British \& Foreign Jurisprudence at 355.

52 Section 1 of the "Act to promote Trade and Manufacture, by regulating and encouraging Partnerships" 1781 (21 \& 22 Geo III, c 46).

53 Idem $\mathrm{s} 1$.

54 Idem $\mathrm{s} 6$.

55 Idem $\mathrm{s} 8$.

56 Ibid.

57 See infra and $c f$ UK Partnership Act, 1907 (7 Edw VII, c 24) sec 6(2).

58 B Ker Report on the Law of Partnership vol 44 (London, 1837) at 439.

59 Appendix 22 idem at 21.

60 Ker (n 58) at 21. See, also, SJ Strahan \& KM Oldham "Book review of The Law of Partnership" (1924) $J$ of the Societies of Public Teachers of Law at 45.

61 By the Companies Act 1862 (25 \& 26 Vict c 89). 
The limited partnership was re-introduced in Ireland only with the enactment of the Limited Partnerships Act of $1907^{62}$ in the United Kingdom, with effect from 1 January 1908.

\section{Revised New York Limited Partnerships Act of 1829}

The earliest legislation inspired by the provisions of the 1807 French Code de Commerce and introduced in a common-law jurisdiction, appears to be the New York "Act relative to Partnerships" of $1822 .{ }^{63}$ It also serves as the first instance in the history of New York legislation when the statute law of any country other than England was closely imitated and adopted. ${ }^{64}$ It was passed on 17 April 1822, after which Connecticut soon followed with a similar statute. ${ }^{65}$ The New York statute was revised in 1829. This statute "[o]f limited partnerships", as it is termed in the New York Revised Statutes of 1829, was soon re-enacted in almost all of the existing states, ${ }^{66}$ so that at the turn of the nineteenth century, legislative authority for limited partnerships existed in nearly every political jurisdiction in the United States. ${ }^{67}$ These were followed by Uniform Limited Partnership Acts in the twentieth and twenty-first centuries. ${ }^{68}$

For the purposes of this discussion, the influential New York Revised Limited Partnership Act of $1829^{69}$ will serve as basis. ${ }^{70}$

62 Limited Partnerships Act 1907 (7 Edw VII c 24).

63 Burdick (n 40) at 383.

64 Troubat (n 11) at 26.

65 Both of these states passed statutes in the year 1822 - New York on 17 Apr and Connecticut on 29 May. The two statutes were very similar, although Connecticut courts strenuously denied that its statute was in any way copied from New York's, insisting that both were derived from the French law. See EA Gilmore Handbook on the Law of Partnership including Limited Partnerships (St Paul, Minn, 1911) at 594.

66 Among the earliest were Massachusetts on 10 Mar 1835; Pennsylvania on 21 Mar 1836; New Jersey on 9 Feb 1837; Michigan on 18 Mar 1837; Virginia on 29 Mar 1837; Mississippi on 15 Feb 1838; Vermont on 19 Nov 1839; Ohio on 24 Jan 1846; Illinois on 23 Feb 1847; Kentucky on 26 Feb 1850; New Hampshire on 13 Jul 1855; and Indiana on 5 Mar 1859.

67 FH O’Neal "Comments on recent developments in limited partnership law" (1978) Washington University Law Quarterly at 670.

68 The full texts of all Uniform Limited Partnership Acts are available through Westlaw at http:// international.westlaw.com/toc/default.wl $r s=$ WLIN15.07\&scdb=ULA\&vr $=2.0 \& a b b r=U L A \& s c$ $r l t=C L I D \_D B 56138932638 \& r p=\% 2 f t o c \% 2 f d e f a u l t . w l \& s p=i n t u f s-000 \& f n=t o p \& t f=2004 \& m t$ $=314 \& t c=29 \& s v=F u l l$ ). According to the National Conference of Commissioners on Uniform State Laws, the new Limited Partnerships Act of 2001 is a stand-alone act. As a result, it is far more comprehensive and complex than its immediate predecessor.

69 Termed "Of limited partnerships" in the New York Revised Statutes of 1829 (New York Code Article 8A) (hereafter the New York Revised Limited Partnership Act of 1829).

70 See C Crary The Law in Respect to Limited Partnerships and Compromises by Partners and Joint Debtors in the State of New York (Albany, 1866) at 5. 
A New York limited partnership consisted of one or more general partners and one or more special partners. ${ }^{71}$ The general partners were liable jointly and severally for partnership debts, and were the only partners authorised to transact business on behalf of, sign for and bind the partnership. ${ }^{72}$ A special partner contributed a specific sum in cash as capital, and was not liable for the debts of the partnership beyond the specific sum contributed. ${ }^{73}$

A limited partnership could be formed for the transaction of any mercantile, mechanical or manufacturing business. Interestingly, banking was excluded, similar to the Irish legislation, and as a further limitation, insurance as well. ${ }^{74}$ Persons who sought to form a limited partnership had to draw up a certificate, containing the prescribed detailed information required, signed by each partner. ${ }^{75}$ Detailed requirements were also set for the acknowledgement by witnesses, certification and filing of the certificate, ${ }^{76}$ which had to be filed at the office of the clerk of the county in which the principal place of business of the partnership was to be situated. It had to be recorded in a register open for public inspection. ${ }^{77}$ At the same time, the general partners had to file an affidavit stating that the special partners had paid the sums specified in the certificate into the common stock in cash. ${ }^{78}$ Thereafter, the terms of the partnership had to be published in two newspapers in the county where the registration had taken place. ${ }^{79}$ Every renewal or continuation of the partnership, and any alteration made to any other matter specified in the certificate, had to be similarly certified, acknowledged and recorded. ${ }^{80}$

The business of the partnership had to be conducted under a firm in which only the names of the general partners had to be inserted, without the words "and company". If the name of any special partner was used in the firm with such partner's consent, he was deemed a general partner ${ }^{81}$ The general partners were accountable to each other and to the special partners for the management of the concern. ${ }^{82}$

71 Section 2 of the New York Revised Limited Partnership Act of 1829.

72 Section 3 of the New York Revised Limited Partnership Act of 1829.

73 Section 2 of the New York Revised Limited Partnership Act of 1829.

74 Section 1 of the New York Revised Limited Partnership Act of 1829.

75 Inter alia containing the name of the partnership; the general nature of the business; the names of the general as well as the special partners, specifying which is which; their respective places of residence; the amount of capital contributed by each special partner; and the dates of commencement and termination of the partnership.

76 In essence, the same formalities for acknowledgement and certification as required for conveyances of land had to be complied with.

77 Section 6 of the New York Revised Limited Partnership Act of 1829.

78 Section 7 of the New York Revised Limited Partnership Act of 1829.

79 Section 9 of the New York Revised Limited Partnership Act of 1829.

80 Sections $11 \& 12$ of the New York Revised Limited Partnership Act of 1829.

81 Section 13 of the New York Revised Limited Partnership Act of 1829.

82 Section 18 of the New York Revised Limited Partnership Act of 1829. 
A special partner could not transact any business on account of the partnership nor be employed as an agent, attorney or otherwise for that purpose. However, he could from time to time examine the state and progress of the partnership's concerns and advise as to their management. If he acted contrary to these provisions and interfered in the management, he was deemed to be a general partner. ${ }^{83}$

If it appeared that, by the payment of interest or profits to a special partner, the original capital had been reduced, that partner was bound to restore the amount necessary to make good his share of the capital. ${ }^{84}$ In the event of insolvency or bankruptcy of the partnership, a special partner could under no circumstance claim as a creditor until the claims of all the external creditors of the partnership were satisfied. ${ }^{85}$

Several provisions were devoted to fraud and misconduct in insolvency, and the concomitant liabilities of and consequences for the partners. ${ }^{86}$

Compared to the original legislation of 1822, the revised New York statute of 1829 created a much more modern impression and reflected more considered drafting. The 1822 statute did not limit the scope of the activities of limited partnerships in general, while the revised Act did. ${ }^{87}$ As already stated, the original and the revised statute prohibited the partnership from engaging in banking or insurance. Neither contained the strict limitations on the minimum and maximum amounts that could be contributed by special partners, on the duration of the partnership and the percentage of the profits that could be withdrawn annually, found in the Irish statute of $1781{ }^{88}$ On the other hand, neither the original nor the revised New York statute contained provisions similar to those of the Irish statute that stipulated the non-dissolution of the partnership and the succession of a special partner in the event of his death or bankruptcy, or the non-dissolution of the partnership in the event of the death of one of the several general partners. In fact, provisions stipulating that the limited partnership would not be dissolved upon the death or bankruptcy of a limited partner were only introduced by the Limited Partnerships Act of $1907^{89}$ in the United Kingdom and the Uniform Limited Partnership Act of $1916^{90}$ in the United States.

Nevertheless, in the same way that the Irish statute of 1781 was included in Ker's Report on the Law of Partnership in 1837 as an example of what was regarded illconsidered partnership legislation, the New York Revised Limited Partnership Act of

83 Section 17 of the New York Revised Limited Partnership Act of 1829.

84 Section 16 of the New York Revised Limited Partnership Act of 1829.

85 Section 23 of the New York Revised Limited Partnership Act of 1829.

86 Sections 19-22 of the New York Revised Limited Partnership Act of 1829.

87 Section 1 of the New York Limited Partnership Act of 1822.

88 "Act to promote Trade and Manufacture, by regulating and encouraging Partnerships" of 1781 (21 \& 22 Geo III, c 46).

89 Limited Partnerships Act 1907 (7 Edw 7, c 24) s 6(2).

90 Limited Uniform Partnership Act of 1916 ss 19-21. 
1829 was included as an appendix to Ker's report ${ }^{91}$ as an example worth following in framing similar legislation in the United Kingdom. ${ }^{92}$ The working of the statute was hailed as beneficial, as it created the means to direct capital to commercial enterprise that would otherwise have been employed elsewhere. ${ }^{93}$ It also enabled a retiring trader to leave a portion of his gains in the business and thereby pass on the business to his successors, which he might not have been inclined to do if his entire fortune were liable to the partnership engagements. ${ }^{94}$

Previously, little was known about the effects of the New York Revised Limited Partnership Act of 1829, but, fortunately, a very comprehensive analysis of the use of the limited partnership in nineteenth-century New York City was recently completed. It appears that the limited partnership was adopted by a surprisingly large number of firms, and that these partnerships had more capital, boasted lower rates of failure and had fewer members with kinship ties than ordinary partnerships. The results suggest that the introduction of the limited partnership facilitated investments that would not have occurred in the absence of this legislation. ${ }^{95}$

\section{Colonial statutes in Australia and New Zealand}

Twomey ${ }^{96}$ maintains that the Irish Anonymous Partnerships Act was adopted as the Anonymous Partnerships Act of 1853 in New South Wales, ${ }^{97}$ in South Australia, ${ }^{98}$ and in Victoria. ${ }^{99}$ However, Fletcher ${ }^{100}$ believes that only the concept of limiting liability was adopted in limited partnerships statutes in New South Wales, Victoria and South Australia in the 1850s. ${ }^{101}$

Upon closer inspection, it appears that the statutes of New South Wales, South Australia and Victoria were not designated "Anonymous Partnerships Act", but rather "An Act to Legalise Partnerships with Limited Liability" in New South Wales and Victoria, and "An Act to Legalize Partnerships with Limited Liabilities" in South Australia. These statutes were almost identical for all intents and purposes, and all three were enacted in the course of 1853. All three provided for limited partnerships consisting of general and special partners, and not for anonymous partnerships

$91 \operatorname{Ker}(\mathrm{n} 58)$ at 439.

92 Idem at 22.

93 Idem at 21.

94 Ibid.

95 E Hilt \& K O’Banion “The limited partnership in New York 1822-1858: Partnerships without kinship" (2009) The J of Economic History at 615.

96 See M Twomey Partnership Law (Dublin, 2000) at 9.

$97 \quad 17$ Vict c 9.

$98 \quad 17$ Vict c 20.

$99 \quad 17$ Vict c 5.

100 KL Fletcher Higgins and Fletcher The Law of Partnership in Australia and New Zealand (Sydney, 1996) at 267.

101 Ibid. 
consisting of active and anonymous partners, as in the Irish statute. Queensland, which inherited this Act upon separation from New South Wales, retained it in its original form until 1989, when the Partnerships (Limited Liability) Act of 1988 took effect. ${ }^{102}$

New Zealand adopted its Special Partnerships Act in 1858, which provided for special partnerships consisting of general and special partners. ${ }^{103}$ This was preceded by similar legislation in the provinces of Auckland and Wellington. ${ }^{104}$ Except for the difference in terminology, referring to "special" instead of "limited" partnerships, the New Zealand statute was almost identical to the three Australian statutes. According to Fletcher, New Zealand remained the sole user of this "first wave" legislation. ${ }^{105}$ The 1858 Special Partnerships Act was later consolidated into the Mercantile Laws Act of $1880^{106}$ and substantially re-enacted in part 2 of the Partnerships Act of 1908. ${ }^{107}$ The latter was recently repealed by the Limited Partnerships Act of $2008 .{ }^{108}$

The three Australian statutes and the New Zealand Act authorised limited or special partnerships consisting of any number of members to transact agricultural, mining, mercantile, mechanical, manufacturing or other business, except banking and insurance. The members of these partnerships could be either general or special partners. ${ }^{109}$ General partners were liable jointly and severally for partnership debts and obligations. Special partners contributed specific sums of money as capital to the common stock, beyond which they were not liable for any of the partnership debts. ${ }^{110}$

102 Partnerships (Limited Liability) Act 78 of 1988. KL Fletcher International Encyclopedia of Laws: Corporations and Partnerships (The Hague, 2010) at 23; KL Fletcher "Limited partnerships and the future" (1977) Queensland Law Society J at 55.

103 Special Partnerships Act 13 of 1858, dated 26 Jun 1858 and titled "An Act to authorise the Formation of Special Partnerships".

104 Respectively "An Act to legalise Partnership with limited liability" Session 2 No 2, and "An Act to authorise the formation of Partnerships consisting of members some having general and others special liability" Session 1 no 10, which were both repealed by s 7 of the Special Partnerships Act of 1858 .

105 Fletcher (n 100) at 267.

106 Mercantile Laws Act 12 of 1880.

107 Partnerships Act 139 of 1907. Fletcher (n 100) at 267. The Partnerships Act 139 of 1908 did not affect the provisions of the Mercantile Laws Act of 1880 relating to special partnerships.

108 Limited Partnerships Act 1 of 2008 According to s 4, the purpose of this Act is to establish a modern regulatory regime for limited partnerships that gives the business community in New Zealand the option of a flexible and internationally recognised business structure similar to limited partnerships in use in overseas jurisdictions, and facilitates the development of the venture capital industry in New Zealand.

109 Section 1 of "An Act to Legalise Partnerships with Limited Liability" of 1853 (New South Wales); "An Act to Legalise Partnerships with Limited Liability" of 1853 (Victoria); "An Act to Legalize Partnerships with Limited Liabilities" of 1853 (South Australia); and the Special Partnerships Act 13 of 1858 (New Zealand).

110 Section 2 of "An Act to Legalise Partnerships with Limited Liability" of 1853 (New South Wales); "An Act to Legalise Partnerships with Limited Liability" of 1853 (Victoria); "An Act to Legalize Partnerships with Limited Liabilities" of 1853 (South Australia); and the Special Partnerships Act 13 of 1858 (New Zealand). 
Before commencing business, all the prospective members had to sign a certificate containing the detailed information required. ${ }^{111}$ In Victoria, South Australia and New South Wales, this certificate had to be registered at the office of the Registry of Deeds, and in New Zealand, in the office of the Supreme Court in a book open for public inspection. ${ }^{12}$ A copy of the certificate had to be published in the Government Gazette and in a newspaper printed nearest to the partnership's principal place of business. If not, the partnership was deemed to be a general partnership. ${ }^{113}$

The firm name had to contain the names of the general partners only, or the name of one such partner with the addition of "and Company" in New Zealand, ${ }^{114}$ or "and another" or "and others" in the three Australian jurisdictions. ${ }^{115}$ Only the general partners were entitled to transact the business of the partnership. If the name of any special partner was used with his consent or privity in the carrying on of such business or any contract connected therewith, or if he personally entered into any contract in respect of the concerns of the partnership, he was deemed to be a general partner in that particular matter or contract. ${ }^{116}$

In New South Wales, Victoria and New Zealand, the partnership could not be entered into for more than seven years, but could be renewed at the end of that period or upon the termination of any shorter period for which it was formed. ${ }^{117}$ The South Australian statute ${ }^{118}$ did not contain such a limitation.

111 Section 3 of all four statutes ("An Act to Legalise Partnerships with Limited Liability" of 1853 (New South Wales); “An Act to Legalise Partnerships with Limited Liability” of 1853 (Victoria); "An Act to Legalize Partnerships with Limited Liabilities" of 1853 (South Australia); and the Special Partnerships Act 13 of 1858 (New Zealand)) required the style or firm under which the partnership was to be conducted; details of all the partners, distinguishing the general from the special partners; the amount of capital contributed by each special partner as well as details of other contributions; the general nature of the business of the partnership; its principal place of business; and its commencement and termination dates.

112 Section 5 of all four statutes ("An Act to Legalise Partnerships with Limited Liability" of 1853 (New South Wales); "An Act to Legalise Partnerships with Limited Liability" of 1853 (Victoria); "An Act to Legalize Partnerships with Limited Liabilities" of 1853 (South Australia); and the Special Partnerships Act 13 of 1858 (New Zealand)).

113 Section 6 of all four statutes ("An Act to Legalise Partnerships with Limited Liability" of 1853 (New South Wales); “An Act to Legalise Partnerships with Limited Liability” of 1853 (Victoria); "An Act to Legalize Partnerships with Limited Liabilities" of 1853 (South Australia); and the Special Partnerships Act 13 of 1858 (New Zealand)).

114 New Zealand s 4.

115 New South Wales, s 4; Victoria s 4; and South Australia s 4.

116 Section 4 of all four statutes ("An Act to Legalise Partnerships with Limited Liability" of 1853 (New South Wales); "An Act to Legalise Partnerships with Limited Liability" of 1853 (Victoria); "An Act to Legalize Partnerships with Limited Liabilities" of 1853 (South Australia); and the Special Partnerships Act 13 of 1858 (New Zealand)).

117 Section 7 of "An Act to Legalise Partnerships with Limited Liability" of 1853 (New South Wales); "An Act to Legalise Partnerships with Limited Liability" of 1853 (Victoria); and the Special Partnerships Act 13 of 1858 (New Zealand).

118 "An Act to Legalize Partnerships with Limited Liabilities" of 1853 (South Australia). 
If renewed or continued beyond the time originally agreed upon for the partnership's duration, a certificate of this renewal or continuation had to be signed, acknowledged, registered and published in the same manner as the original certificate. If not, the partnership was deemed to be general. ${ }^{119}$ In any event, no dissolution of the partnership could take place, except by operation of law, before the time specified in the certificate, unless a notice of such dissolution was signed, acknowledged, registered and published in the same way as the original certificate. ${ }^{120}$

In the course of the partnership, no part of the certified capital could be withdrawn nor could a division of interest or profit be made so as to reduce the capital below the aggregate amount stated in the certificate. If this prohibition was not observed, and it rendered the assets insufficient to pay the partnership debts, the special partners became severally liable to refund every sum so received. ${ }^{121}$

General partners were liable to account to each other and to the special partners for their management of the partnership concerns. The ordinary principles of the law of partnership applied. ${ }^{122}$ General partners were obligated to see to regular bookkeeping in respect of the partnership concerns, and to make available such books for inspection by the special partners at all reasonable times. If not, the special partners were entitled to have the partnership dissolved, and to have its accounts taken by the Supreme Court. ${ }^{123}$ In South Australia, such default by the general partners resulted in their forfeiture to the special partners of their profits or share of the profits, as the Supreme Court deemed fit in the circumstances. ${ }^{124}$

119 Section 8 of "An Act to Legalise Partnerships with Limited Liability" of 1853 (New South Wales); "An Act to Legalise Partnerships with Limited Liability" of 1853 (Victoria); and the Special Partnerships Act 13 of 1858 (New Zealand). See, also, s 8 of "An Act to Legalize Partnerships with Limited Liabilities" of 1853 (South Australia).

120 Section 10 of "An Act to Legalize Partnerships with Limited Liabilities" of 1853 (South Australia); Section 11 of "An Act to Legalise Partnerships with Limited Liability" of 1853 (New South Wales); "An Act to Legalise Partnerships with Limited Liability" of 1853 (Victoria); and the Special Partnerships Act 13 of 1858 (New Zealand). Interestingly, ss 11 and 12 of the Special Partnerships Act 13 of 1858 (New Zealand) referred to a limited partnership, and not a special partnership as in its other sections.

121 Section 8 of "An Act to Legalize Partnerships with Limited Liabilities" of 1853 (South Australia); s 9 of "An Act to Legalise Partnerships with Limited Liability" of 1853 (New South Wales); "An Act to Legalise Partnerships with Limited Liability" of 1853 (Victoria); and the Special Partnerships Act 13 of 1858 (New Zealand).

122 Section 12 of "An Act to Legalize Partnerships with Limited Liabilities" of 1853 (South Australia); s 13 of "An Act to Legalise Partnerships with Limited Liability" of 1853 (New South Wales); "An Act to Legalise Partnerships with Limited Liability" of 1853 (Victoria); and the Special Partnerships Act 13 of 1858 (New Zealand).

123 Section 15 of "An Act to Legalise Partnerships with Limited Liability" of 1853 (New South Wales); "An Act to Legalise Partnerships with Limited Liability" of 1853 (Victoria); and the Special Partnerships Act 13 of 1858 (New Zealand).

124 Section 14 of "An Act to Legalize Partnerships with Limited Liabilities" of 1853 (South Australia). 
In Victoria and New South Wales, however, it was expressly provided that the special partners were also obligated to ensure that regular books of account were kept. This provision did not appear in the statutes of New Zealand or South Australia. The statutes of Victoria, New South Wales and New Zealand further provided that if the partnership's books were kept incorrectly, or contained false or deceptive entries whereby the determination of the maintenance of capital ${ }^{125}$ was or may have been affected, and this occurred with the knowledge or privity of all or any of the special partners, the certified capital of the relevant special partners was deemed to have been withdrawn, and they incurred liability accordingly. ${ }^{126}$ The South Australian statute did not contain a similar provision.

In South Australia, a partner who used the money of the partnership on his own private account or for any separate purpose of his own without the written consent of his partners was deemed to have committed a misdemeanour, and was liable on conviction to a pecuniary fine. ${ }^{127}$

In all cases where these statutes did not provide otherwise, all the members of the partnership were subject to the liabilities and entitled to the rights of general partners. ${ }^{128}$

All lawsuits regarding the business of the partnership had to be prosecuted by and against the general partners only, except where the statute provided that the special partners had to or could be deemed as general partners. In such a case, every special partner liable as a general partner could be joined as a defendant at the discretion of the party suing. ${ }^{129}$

A partner guilty of any fraud in the affairs of the partnership was civilly liable to the party injured to the extent of his damage, and was also liable for a misdemeanour, punishable by fine, imprisonment or both. ${ }^{130}$

125 As provided for in $\mathrm{s} 9$.

126 Section 16 of "An Act to Legalise Partnerships with Limited Liability" of 1853 (New South Wales); "An Act to Legalise Partnerships with Limited Liability" of 1853 (Victoria); and the Special Partnerships Act 13 of 1858 (New Zealand).

127 Section 14 of "An Act to Legalize Partnerships with Limited Liabilities" of 1853 (South Australia).

128 Section 11 of "An Act to Legalize Partnerships with Limited Liabilities" of 1853 (South Australia); s 12 of "An Act to Legalise Partnerships with Limited Liability" of 1853 (New South Wales); "An Act to Legalise Partnerships with Limited Liability" of 1853 (Victoria); and the Special Partnerships Act 13 of 1858 (New Zealand).

129 Section 9 of "An Act to Legalize Partnerships with Limited Liabilities" of 1853 (South Australia); s 10 of "An Act to Legalise Partnerships with Limited Liability" of 1853 (New South Wales); "An Act to Legalise Partnerships with Limited Liability" of 1853 (Victoria); and the Special Partnerships Act 13 of 1858 .

130 Section 13 of "An Act to Legalize Partnerships with Limited Liabilities" of 1853 (South Australia); s 14 of "An Act to Legalise Partnerships with Limited Liability" of 1853 (New South Wales); "An Act to Legalise Partnerships with Limited Liability" of 1853 (Victoria); and the Special Partnerships Act 13 of 1858 (New Zealand). 
Although it has been said that the New Zealand Special Partnerships Act of 1858 is based on the Irish Anonymous Partnerships Act of 1781, ${ }^{131}$ the comparison shows a markedly closer affinity between the New Zealand statute, the three Australian statutes of 1853 and the New York Limited Partnerships Act as revised in 1829, than between the New Zealand and Irish legislation.

\section{Cape and Natal Acts}

\section{Overview}

The limited partnership was provided for in the Cape and Natal respectively by the Cape Special Partnerships Limited Liability Act of $1861^{132}$ (hereinafter "the Cape Act"), as amended by the Cape Special Partnerships Limited Liability Amendment Act of $1906^{133}$ (hereinafter "the Cape Amendment Act"), and the Natal Special Partnerships Limited Liability Act of 1864 (hereinafter "the Natal Act"). ${ }^{134}$

Notably, in the Cape, the option of limited liability for all, and not only some, members of a joint stock company was also introduced in 1861 by the Joint-stock Companies Limited Liability Act of $1861,{ }^{135}$ which also limited the number of partners in an unincorporated partnership to twenty five. ${ }^{136}$ The latter was based on the British Joint Stock Companies Act of $1844^{137}$ and the Limited Liability Act of $1855,{ }^{138}$ which, by the time of their introduction to the Cape, had already been consolidated and repealed by the British Joint Stock Companies Act of 1856, ${ }^{139}$ the first modern British companies act. ${ }^{140}$ Natal followed suit with the Law to Limit the Liability of Members of Certain Joint-stock Companies of 1864. ${ }^{141}$

Both the Cape and Natal Acts provided for limited partnerships ${ }^{142}$ consisting of one or more general partners and one or more special partners. In the Cape, these partnerships could be formed for the transaction of any mercantile, mechanical or manufacturing business, and in Natal, for agricultural or pastoral farming as well. ${ }^{143}$

131 See par II(b) supra.

132 Special Partnerships Limited Liability Act 24 of 1861 (Cape).

133 Special Partnerships Limited Liability Amendment Act 12 of 1906 (Cape).

134 Special Partnerships Limited Liability Act of 1864 enacted by Law 1 of 1865 (Natal), of which s 14 provided: "The Law shall be cited for all purposes as 'The Special Partnerships Limited Liability Act, 1864.

135 Joint-stock Companies Limited Liability Act of 231861 (Cape).

136 Section 1 of the Joint Stock Companies Limited Liability Act of 1861 (Cape).

137 Joint Stock Companies Act 1844 (7 \& 8 Vict c 110).

138 Joint Stock Companies Act 1856 (18 \& 19 Vict c 133).

139 See, esp, In re Paarl Bank (1891) 8 SC 131 at 136; E Carstens ca C W Neebe 1883 OFS 10 at 13.

140 PL Davies Gower and Davies' Principles of Modern Company Law (London, 2003) at 4.

141 Law to Limit the Liability of Members of Certain Joint-stock Companies 10 of 1864 (Natal).

142 The headings referred to a "limited liability partnership".

143 Section 2 of both laws. Special Partnerships Limited Liability Act 24 of 1861 (Cape) and the Special Partnerships Limited Liability Act, 1864 (Law 1 of 1865) (Natal). 
These partnerships could not be formed for the purpose of banking in either the Cape or Natal. ${ }^{144}$ The partnership had to be registered in the office of the Registrar of Deeds. Section 1 of the Cape Amendment Act ${ }^{145}$ required the names of limited partnerships in the Cape to bear the word "Registered".

The general partners were jointly and severally liable for partnership debts and obligations. They were the only ones authorised to transact business on behalf of, sign for and bind the partnership. The special partners contributed a specific sum in cash to the common stock. They were not personally liable for any debts of the partnership beyond the amount that they paid, except where the law provided otherwise. Even then, nothing in the legislation rendered a special partner liable for any debts contracted by the general partners prior to the formation and registration of the limited partnership. ${ }^{146}$

Business had to be conducted under a name or firm that did not include the name of any special partner, the word "company" or any other general term. If the name of a special partner was used in the firm with his consent or knowledge, the special partner was deemed and treated as a general partner. ${ }^{147}$

A special partner was prohibited from transacting any business on account of the partnership, or being employed as agent, attorney or otherwise for that purpose, and risked forfeiting his privileges for violation of this prohibition. However, he could from time to time enquire into the state and progress of the partnership concerns and advise as to their management. ${ }^{148}$ If the special partner personally entered into any transaction or concluded any contract regarding the concerns of the partnership with any person except the general partners, he was deemed and treated as a general partner in relation to such transaction or contract, unless it appeared that in entering into such transaction or concluding such contract, he acted as a special partner only. ${ }^{149}$

At no stage in the course of the partnership could a special partner withdraw any part of the sum that he paid into the capital stock and that had been stated in the certificates required for registration, or pay and transfer to himself such funds in the form of dividends, profits or otherwise. However, any partner could annually receive interest on the sum he contributed if the payment of such interest did not reduce the amount of the capital to below the amount originally paid in. If, after the payment

144 Section 1 of both laws: Special Partnerships Limited Liability Act 24 of 1861 (Cape) and the Special Partnerships Limited Liability Act, 1864 (Law 1 of 1865) (Natal).

145 Act 12 of 1906.

146 Section 3 of both laws: Special Partnerships Limited Liability Act 24 of 1861 (Cape) and the Special Partnerships Limited Liability Act, 1864 (Law 1 of 1865) (Natal).

147 Section 7 of both Special Partnerships Limited Liability Act 24 of 1861 (Cape) and the Special Partnerships Limited Liability Act, 1864 (Law 1 of 1865) (Natal). Provision was made for a partner retiring from the management and conduct of the business to continue as a special partner.

148 Section 12 of both the Special Partnerships Limited Liability Act 24 of 1861 (Cape) and the Special Partnerships Limited Liability Act, 1864 (Law 1 of 1865) (Natal).

149 Ibid. 
of the interest, any profits remained to be divided, the partner could also receive his portion of such profits. However, if it appeared that by the payment of interest or profits to any special partner, the original capital had been reduced, the receiving partner was bound to restore the amount necessary to make good his share of capital, with interest, from the date of the withdrawal. ${ }^{150}$

Persons forming a limited partnership had to make and severally sign a certificate that contained the name or firm under which the partnership was to be conducted; the names and residences of all the general and special partners, distinguishing who were general and who were special partners; the amount of capital that each special partner paid into the common stock; the general nature of the business to be transacted, and the time when the partnership was to commence as well as terminate. ${ }^{151}$

No limited partnership was deemed to have been formed until the certificate containing the required particulars was acknowledged by all the partners before a justice of the peace, and registered in the office of the Registrar of Deeds in a book to be kept for that purpose, which had to be open to public inspection. ${ }^{152}$ Where the certificate contained a false statement, all the stakeholders in the partnership were regarded as general partners for all partnership engagements. ${ }^{153}$

Upon a renewal or continuation of a limited partnership beyond the time originally agreed upon for its duration, a certificate had to be made, acknowledged and registered in the same manner as provided for the original formation of the limited partnerships. Where a partnership was renewed and continued, but not in conformity with these requirements, all the partners were deemed and taken to be general partners and, as such, were liable for all the engagements of the partnership. ${ }^{154}$

All lawsuits regarding the business of a limited partnership had to be brought and prosecuted by and against the general partners as if there were no special partners. Where the special partners were deemed general partners, and special partnerships were deemed general partnerships, all the partners deemed general partners could join or be joined in the litigation. ${ }^{155}$

The general partners had to account to each other and to the special partners for their management of the business. ${ }^{156}$ Where a limited partnership became insolvent,

150 Section 11 of both Special Partnerships Limited Liability Act 24 of 1861 (Cape) and the Special Partnerships Limited Liability Act, 1864 (Law 1 of 1865) (Natal).

151 Section 4 of both the Special Partnerships Limited Liability Act 24 of 1861 (Cape) and the Special Partnerships Limited Liability Act, 1864. (Law 1 of 1865) (Natal).

152 Section 5 of both the Special Partnerships Limited Liability Act 24 of 1861 (Cape) and the Special Partnerships Limited Liability Act, 1864 (Law 1 of 1865) (Natal).

153 Ibid.

154 Section 6 of both the Special Partnerships Limited Liability Act 24 of 1861 (Cape) and the Special Partnerships Limited Liability Act, 1864 (Law 1 of 1865) (Natal).

155 Section 8 of both the Special Partnerships Limited Liability Act 24 of 1861 (Cape) and the Special Partnerships Limited Liability Act, 1864 (Law 1 of 1865) (Natal).

156 Section 13 of both the Special Partnerships Limited Liability Act 24 of 1861 (Cape) and the Special Partnerships Limited Liability Act, 1864 (Law 1 of 1865) (Natal). 
no special partner could under any circumstances claim as a creditor until all the claims of all the other creditors of the partnership were satisfied. ${ }^{157}$

Any alteration made to the names of the partners, the nature of the business, the amount of capital thereof or any other matter stated in the original certificate was regarded as the dissolution of the partnership. A partnership that was carried on after an alteration had been made was deemed a general partnership, except if it was renewed as a special partnership as prescribed. ${ }^{158}$

Except by operation of another law, no dissolution of a limited partnership could take place before the time specified in the registered certificate, unless a notice of the dissolution was registered in the Deeds Registry Office and in every civil commissioner's office in which the original certificate of renewal or continuation of the partnership had been registered, and unless the notice was also published for no less than three successive weeks in the Government Gazette as well as in a newspaper published in the division(s) where the registration certificate or the certificate of the renewal or continuation of the partnership had been registered. If no newspaper was published in the division at the time of the dissolution, the notice of dissolution had to be published for no less than three successive weeks in any newspaper published in the town or village nearest to the division(s) where the certificate had been registered. ${ }^{159}$

Although neither the Cape nor the Natal Act placed any limitation on the number of partners, the Companies Act of 1926 reduced the maximum number of partners in an unincorporated partnership to twenty. ${ }^{160}$ This limitation was maintained by the Companies Act of 1973, although provision was made for the exemption of certain professional partnerships. ${ }^{161}$ It was repealed by the Companies Act of $2008 .{ }^{162}$

\section{Origin}

Some authors described the introduction of the limited partnership in the Cape and Natal as unnecessary and yet another example of the slavish imitation of legislation of the United Kingdom. ${ }^{163}$ However, upon closer inspection, it appears that the Cape and Natal Acts were in fact not modelled after any legislation of the United Kingdom.

157 Section 14 of both the Special Partnerships Limited Liability Act 24 of 1861 (Cape) and the Special Partnerships Limited Liability Act, 1864 (Law 1 of 1865) (Natal).

158 Section 10 of both the Special Partnerships Limited Liability Act 24 of 1861 (Cape) and the Special Partnerships Limited Liability Act, 1864 (Law 1 of 1865) (Natal).

159 Section 9 of both the Special Partnerships Limited Liability Act 24 of 1861 (Cape) and the Special Partnerships Limited Liability Act, 1864 (Law 1 of 1865) (Natal).

160 Companies Act 46 of 1926, 4. This provision was based on 4 of the Transvaal Companies Act 31 of 1909. As such, it was taken over directly from UK company legislation.

161 Companies Act 61 of 1973, s 30.

162 Companies Act 71 of 2008.

163 JC de Wet \& AH Van Wyk Kontraktereg en Handelsreg (Durban, 1978) at 417. 
The United Kingdom was much slower than many other countries to introduce a form of partnership in which non-managing partners could have limited liability. In 1882, Sir Frederick Pollock went so far as to observe that "the institution of partnership en commandite, or limited partnership ... is unknown in the United Kingdom, and in these kingdoms alone ... among all the civilised countries of the world". ${ }^{164}$ Ker's comprehensive Report on Partnership Law ${ }^{165}$ in 1837 referred particularly to the expedience of introducing the concept of the partnership en commandite based on the French model in the United Kingdom. Later developments reveal some confusion between the introduction of this kind of limited liability for non-managing partners, and attempts to mitigate the implications of the usury doctrine-inspired construct that rendered any person who shared in the profits of the partnership liable for the debts of the partnership, even creditors. ${ }^{166}$ Relief for profitsharing lenders was finally effected by the House of Lords in Cox v Hickman ${ }^{167}$ and by the 1865 Act to Amend the Law of Partnership, also known as "Bovill's Act", 168 although this did not imply limited liability for non-managing partners in the sense of the partnership en commandite. The limitation of liability for partners excluded from management functions was attained in Britain only with the introduction of the Limited Partnerships Act 1907, ${ }^{169}$ which took effect on 1 January 1908, more than forty years after the Cape and Natal Acts .

On the face of it, the introduction of the Cape and Natal Acts was rather motivated by the concerted effort in colonial and other common-law jurisdictions to introduce limited partnership legislation inspired by the provisions on the société en

164 F Pollock Essays in Jurisprudence and Ethics (London, 1882) at 100.

165 Ker (n 58) at 439.

166 Grace v Smith (1775) 2 Wm Bl 997, 96 ER 587. See, also, Canada Deposit Insurance Corporation v Canadian Commercial Bank [1992] 3 SCR 558. Thus, the Select Committee on the Law of Partnership of 1851 considered the issue of limited liability in a partnership context, but recommended that this question be referred to a royal commission of adequate legal and commercial knowledge. As a result, the Commission on the Mercantile Laws and on the Law of Partnership of 1854 was appointed. The commission failed to reach unanimity. A bare majority opposed the 1851 proposal that a person should be able to lend money to a partnership at an interest rate related to its profits, without incurring partnership liability. This was followed by a unanimous resolution of the House of Commons that the law of partnership should be amended by the introduction of limited liability for profit-sharing contributors of capital. In the next session of Parliament, the Partnerships Amendment Bill reaffirmed the proposal of the 1851 committee to allow profit-sharing loans to partnerships, without the lender incurring the liability of a partner. It progressed to a second reading, but did not go any further, despite the earlier resolution of the House. In 1856, a similar Partnerships Amendment Bill was tabled. The Bill had a third reading in the House of Commons, but was not implemented. For a detailed discussion, see JJ Henning \& MS Wandrag "Limited companies and limited partnerships in English law - a historical watershed" (1997) J for Juridical Science at 150.

167 Cox v Hickman (1860) 8 HLC 268, 11 ER 431.

$16828 \& 29$ Vict c 86.

169 Limited Partnerships Act 1907 (7 Edw 7, c 24). 
commandite found in Louis XIVs Ordinance of 1673 and/or the Code de Commerce of 1807. ${ }^{170}$ It appears that, in this regard, the New York Revised Limited Partnership Act of $1829,{ }^{171}$ played a more significant and influential part than the Irish limited partnership statute of $1783 .{ }^{172}$

\section{Fortunes}

\section{South Africa}

Because of the prior reception in South Africa of the partnership en commandite via Roman-Dutch law, as well as the availability of limited liability for all members under the various companies statutes instead of only for some members in a limited partnership, the Natal and Cape statutes did not prove popular. In South Africa, the Natal and Cape statutes were eventually repealed by the Pre-Union Statute Law Revision Act of $1976,{ }^{173}$ but not with retroactive effect.

The repeal of the Natal and Cape Act as well as the Cape Amendment Act ${ }^{174}$ by the South African Pre-Union Statute Law Revision Act of $1976^{175}$ did not result ipso jure in the repeal of the Cape statutes as they applied in the Southern African jurisdictions referred to below.

\section{Southern Africa}

Both Roman-Dutch common law and the statutory law then in force in the Cape Colony was introduced in the then Basutoland (present-day Lesotho) in 1884, in Southern Rhodesia (present-day Zimbabwe) in 1898 as well as the then Bechuanaland (present-day Botswana) in 1909, and in the law existing in the province of the Cape of Good Hope in South West Africa (now Namibia) in 1920. ${ }^{176}$ Thus the Cape Act was introduced in all four jurisdictions, and the Cape Amendment Act only in Namibia.

The Cape Act was repealed and substantially re-enacted by Part II of the Partnerships Proclamation of $1957^{177}$ in Lesotho and by the Special Partners Limited Liability Act of $1963^{178}$ in Zimbabwe.

170 See JJ Henning "Felicius-Boxelius Tractatus de Societate - 'n Miskende vennootskapsregtelike kenbron uit die ius commune" (1992) THRHR at 446.

171 New York Revised Limited Partnership Act of 1829 (New York Code Article 8A).

172 Irish "Act to promote Trade and Manufacture, by regulating and encouraging Partnerships" 1781 (21\& 22 Geo III, c 46).

173 Act 36 of 1976.

174 Special Partnerships Limited Liability Act 24 of 1861 (Cape); Special Partnerships Limited Liability Amendment Act 12 of 1906 (Cape); and the Special Partnerships Limited Liability Act of 1864 (Law 1 of 1865 (Natal)).

175 Act 36 of 1976.

176 See Hahlo \& Kahn (n 3) at 27.

177 Proclamation 78 of 1957 (Lesotho).

178 Chapter 240 of 1963 (Zimbabwe). 
Section 11 of the Insolvency Act of Botswana, ${ }^{179}$ which deals with the sequestration of the estate of an individual and of a partnership, refers to partners en commandite and anonymous partners, as well as "other partners who have not held themselves out as ordinary or general partners", but not specifically to special partners under the Cape Act. However, a detailed discussion of the law of partnership in Botswana does not contain any reference to statutory limited partnerships. ${ }^{180}$

References in sections 3 and 13 of the Insolvency Act 24 of 1936, inter alia to the "Special Partnerships Limited Liability Act, 1861 (Act 24 of 1861) of the Cape of Good Hope", were deleted in Namibia by the Insolvency Amendment Act 12 of 2005. As one of the purposes of the latter is to delete references to laws that are not applicable in Namibia, these provisions may very well merit a conclusion that the Cape Special Partnerships Limited Liability Act of $1861^{181}$ is not or no longer current in Namibia.

\section{Conclusion}

As far as the origins of the Cape and Natal Acts are concerned, it seems that although Ireland was the first common-law jurisdiction to introduce legislation on limited partnerships, it was unpopular and relatively unknown outside its home jurisdiction, which makes it highly improbable that the Cape and Natal statutes were derived directly from the Irish legislation. The New York legislation, on the other hand, was not only popular, but most influential. It inspired similar legislation in numerous political jurisdictions in America and, especially, also in Australia and New Zealand. This colonial legislation in all probability served as the example for the Cape and Natal statutes. As such, these statutes were ultimately inspired by the provisions of the French Code de Commerce on the société en commandite, which, in turn, was based on the Ordinance Pour le Commerce of 1673.

Although the Cape and Natal statutes were repealed in South Africa more than a century after their introduction, the Cape Act was applied in another four Southern African jurisdictions. It was re-enacted in almost identical legislation in Lesotho and Zimbabwe.

\section{ABSTRACT}

The origins of the Cape Special Partnerships Limited Liability Act of 1861 and the Natal Special Partnerships Limited Liability Act of 1864 have been open to question for quite some time in South Africa. The view that it was taken over directly from the United Kingdom cannot be supported. This contribution traces the origins of this

179 Chapter 42:02 (Botswana).

180 Hahlo \& Kahn (n 3) at 27.

181 Special Partnerships Limited Liability Act 24 of 1861 (Cape). 
legislation through the limited partnership legislation of New Zealand and Australia, back to the influential New York Limited Partnerships Act of 1822, and even further back to the very first limited partnership legislation in a common-law jurisdiction, namely the Irish Anonymous Partnerships Act of 1781, French Code de Commerce and Louis XIV's Ordinance Pour le Commerce of 1673. This supports a conclusion that in the latter Ordinance, limited partnership legislation and the partnership en commandite ultimately share a remote ancestor. In addition, attention is drawn briefly to the fortunes of the Natal and, especially, the Cape legislation in South Africa and four other jurisdictions in Southern Africa. 